\title{
Journalisters syn på journalistisk etik
}

\section{AF ROGER BUCH}

Etik, moral og værdier har fået stor opmærksomhed i de seneste årtier, hvilket også har skabt fokus på journalistisk etik, især på grund af den magt og de potentielt negative konsekvenser journalistikken kan have for politikere, myndigheder, virksomheder og privatpersoner, men også for journalisten og dennes arbejdssted. En spørgeskema-undersøgelse blandt medlemmer af Dansk Journalistforbund viser, at der er en udbredt bevidsthed om journalistisk etik og ret stor tilslutning til udvalgte etiske spørgsmål, men også, at der opleves mange etiske problemer både i medierne generelt og på journalisternes egne arbejdspladser. Den etiske bevidsthed skabes primært gennem egne overvejelser og fejltrin, egen uddannelse, samt samtaler med og observationer af kolleger i hverdagen. Ledelsen på arbejdspladsen samt især Pressenævnet spiller derimod en ringe eller direkte marginal rolle.

„I hvert fald er resultatet, at alle taler om etik, men at det kun er få, der er i stand til at forklare, hvad etik er for et dyr.“

(Sløk, 1993: 5)

Værdier, moral og etik har været et centralt område i dansk og skandinavisk politik siden starten af 1990'erne, hvilket illustreres af Sløks påstand om, at alle taler om etik, men at kun få forstår, hvad etik egentlig er. Synspunktet om etisk og moralsk forfald blev på samme tidspunkt delt af Poul Nyrup Rasmussen, der som 
ny formand for Socialdemokratiet i 1992 i sin første 1. maj tale sagde, at „I Danmark skal vi igen knytte moral og politik sammen. Det har de ikke voret $i$ ti år.“ og lovede at „Vi vil bringe anstcendigheden tilbage i dansk politik“. Den nye danske borgerlige regering satte ti år senere fokus på værdi- og kulturkampen, noget som den nytiltrådte norske statsminister Bondevik gjorde allerede i 1998. Bondevik nedsatte en værdikommission, som fik som hovedmål, at „... bidra til en bred verdimessig og samfunnsetisk mobilisering for å styrke positive fellesskapsverdier og ansvar for miljøet og fellesskapet." Mediernes betydning for formuleringen og udviklingen af værdier i samfundet blev udtrykkeligt fremhævet i værdikommissionens mandat, og et af de seks hovedkapitler i værdikommissionens hovedrapport var rettet imod netop medier og kommunikation. Blandt anbefalingerne heri var, at „vi tilrår at pressen forsterker sine tradisjoner og institusjoner for granskning av egen maktutøvelse og sikring av egen yrkesetikk. Medier og journalistik har altså været kampplads eller arena for de politiske diskussioner om værdier, etik og moral, men journalistikken har også været et område og en aktør i det politiske system, der i sig selv er blevet vurderet, kritiseret og diskuteret ud fra etiske indgangsvinkler. Formålet med denne artikel er ikke at forklare, hvad journalistisk etik er for et dyr, men derimod det mere beskedne at beskrive og analysere, hvorledes journalister opfatter journalistisk etik og dens tilstand anno 2006.

\section{Etik og moral}

Etik og moral bruges i mange af dagliglivets og samfundslivets forhold i flæng, mens filosoffer ofte rangordner de to begreber på den måde, at etik er det mere principielle overordnede grundlag for den mere konkrete moral og de enkelte specifikke moralnormer (Sløk, 1993: 7-9). Hovedparten af de emner, som behandles i forbindelse med journalistisk etik, er imidlertid helt konkrete normer og retningslinjer for journalistisk arbejde, og burde altså ifølge den filosofiske konvention omtales som journalistisk moral. Dette er imidlertid ikke tilfældet, lige som man ikke taler om moral, når man i offentligheden diskuterer fødevare- eller lægeetik, eller når der nedsættes offentlige råd og nævn. Nogle af de 
mest kendte råd er for det første Etisk Råd, som tager stilling til konkrete spørgsmål omkring bl.a. kloning, døendes vilkår, for tidligt fødte børn og samt for det andet de videnskabsetiske komiteer, som godkender lægelig forskning. Der tales heller ikke om moral, men alene om etik, når erhvervs- og brancheorganisationer opstiller etiske regler og har etiske holdninger til så forskellige forhold som eksempelvis byggeri, kvægbrug, helsebranchen og embedsmænds arbejde. Den normale sprogbrug omkring begrebet etik er nærmest den modsatte af den filosofiske konvention - etik bruges om konkrete handlingsanvisninger om, hvad man bør gøre, og hvad man ikke bør gøre, mens moralbegrebet typisk slet ikke bruges i den offentlige politiske debat.

Den omfattende brug af etikbegrebet om alt fra byggeri af et hus, over behandlingen af kvæg til spørgsmålet om, hvornår livet starter og slutter, og hvad man bør og ikke bør gøre i forbindelse med livets start og afslutning, kan føre til en udvanding af etikbegrebet, som i yderste konsekvens gør etik til et indholdsløst begreb. Hvis alt er etik, kan etikken ikke afgrænses fra andre vurderinger af eksempelvis effektivitet, brugbarhed, popularitet osv. Hvis ikke etikbegrebet helt skal opgives, må det særligt etiske afgrænses. Det etiske udspringer af nogle holdnings- eller værdimæssige synspunkter om, at noget er af en vis betydning/vigtighed/vægt, som gør vurderingen til et etisk problem eller en etisk vurdering og ikke blot et problem eller en vurdering. Hvad er det for en vigtighed, som etablerer journalistisk etik, mens der ikke findes etik for mange andre fag? Hvad er begrundelsen for, at der findes diskussioner, lovgivning, institutioner, som forholder sig til journalistisk etik, men ikke findes noget tilsvarende for renovationsarbejdere, bygningsmalere, eller medarbejdere på mejerier?

\section{Journalistisk etik}

Centralt i forklaringen herpå er muligheden for at skade andre, som det også beskrives hos Franklin m.fl.: "Journalism ethics are the moral principles, reflected in rules, written or unwritten, which prescribe how journalists should work to avoid harming or distresing others ..." (Franklin, Hamer, Hanna, Kinsey \& Richard- 
son, 2005: 74). Udgangspunktet i denne artikel er i forlængelse heraf, at det etiske etableres på grund af de især negative konsekvenser, som udøvelsen af journalistik kan have for samfundet, kilderne, journalisten og journalistens ansættelsessted, samt dem eller det som behandles i det journalistiske produkt. Gode såvel som dårlige journalistiske produkter kan have konsekvenser i form af politikere, som får ødelagt deres politiske karriere, virksomheder, som mister deres kunder, enkeltpersoner, som mister deres arbejde, vennekreds, familie eller ægteskab. Der hviler altså et stort ansvar på den enkelte journalist og deres ansættelsessted, når det vælges, hvilke emner der skal behandles, og når det vælges, hvordan emnet skal behandles - samt når emner fravælges og når alternative måder at behandle et emne på fravælges.

Påstanden om, at det er konsekvenser og potentielle konsekvenser, som skaber brugen af begrebet journalistisk etik, skal ikke ses, som en filosofisk stillingtagen i det store slagsmål mellem konsekvensetikere og dydsetikere - teleogisk vs. deontologisk etik (Glebe-Møller, 1996: 12-15) - men alene som en påstand om kausalitet: det er konsekvenser og potentielle konsekvenser, som har skabt diskursen om etik i journalistikken - i modsætning til eksempelvis den manglende diskurs om etik blandt renovationsarbejdere.

I den danske sammenhæng spiller Pressenævnet og den tilhørende lovgivning en stor rolle i indkredsningen af det præcise indhold af journalistisk etik. Dette er behandlet hos både Andersen (2006) og Skovbjerg \& Jørgensen (2006), hvorfor det ikke nærmere skal beskrives her, til gengæld kan Randalls otte etiske principper være illustrative i forhold til typiske elementer i journalistisk etik:

"Journalist should serve only their papers and their readers ... Every story should be an honest search for the truth ...

No inducements to publish should be accepted ...

Journalist should not allow advertisers to influence, directly and indirectly the paper's editorial content ...

Do not use your position to threaten or gain advantage ... Do not promise to suppress stories for friendship or favours ... 
Do not invent or improve information ...

You should not benefit personally from information you acquire ..."

(Randall, 2000: 134-139)

Nogle af principperne kan forekomme, at være overlappende og cirklende omkring mål som sandhedssøgen, objektivitet og upartiskhed. I det følgende beskrives, hvilke holdninger journalister har til sådanne spørgsmål om journalistisk etik, men før dette undersøges først om der overhovedet eksisterer en fælles bevidsthed om journalistisk etik og hvad kilderne er til en sådan bevidsthed. For det andet undersøges omfanget af problemer i danske medier med journalistisk etik. For det tredje undersøges ansvarsplaceringen i.f.t at sikre journalistisk etik. Fjerde fokuspunkt er holdningen blandt undersøgelsens deltagere til konkrete elementer i journalistisk etik, men først en kort præsentation af undersøgelsen og datagrundlaget for analysen.

\section{Datagrundlaget}

Artiklen bygger på en undersøgelsen blandt medlemmer af Dansk Journalistforbund. Undersøgelsen, som rent teknisk blev gennemført af DICAR - Center for analytisk journalistik, bestod af et udtræk på 2075 tilfældigt udvalgte medlemmer af Dansk Journalistforbund, der blev kontaktet via en mail, som indeholdt en introduktion til undersøgelsen, samt et link til et spørgeskema, som skulle udfyldes på internettet. Hvert link var unikt, så den enkelte respondent kun havde mulighed for at besvare eet skema. 745 respondenter eller 36 procent afsluttede hele skemaet, mens yderligere 237 havde besvaret en varierende del af skemaet uden at afslutte besvarelsen - dog ofte kun enkelte spørgsmål. Undersøgelsen blev gennemført marts-april 2006. Svarprocenten på 36 procent er ikke imponerende, men sammenligning af respondenterne på køn og alder tyder ikke på nogen skævhed imellem det samlede udvalg og de respondenter, som valgte at svare. Gennemsnitalderen i det samlede udvalg var 41,5 år, mens den blandt besvarelserne var 41,6 år, og andelen af kvinder i det samlede udvalg var 43,7 procent, mod 42,5 blandt de responden- 
ter som svarede. Der er altså ingen umiddelbar grund til at tvivle på undersøgelsens repræsentativitet, selv om svarprocenten er lav. En dokumentationsrapport for hele undersøgelsen findes på www.rogerbuch.dk/jourundersog.pdf.

\section{Er der en bevidsthed om journalistisk etik og hvad er kilderne hertil?}

En af forudsætningerne for at kunne opdage dårlig journalistisk etik, og for at kunne undgå selv at udøve dårlig journalistisk etik, er, at journalister overhovedet har en bevidsthed om journalistisk etik og gør sig tanker om, hvad der ligger inden for og uden for god journalistisk etik. Findes der en sådan bevidsthed, og hvilke kilder har der været til skabelsen af en sådan bevidsthed? På en seks-punkt skala som går fra 1 (meget lav grad af bevidsthed om journalistisk etik) til 6 (meget høj grad af bevidsthed om journalistisk etik) placerer journalisterne sig selv på en gennemsnitscore på 5,0, mens de placerer danske journalister generelt på en gennemsnitscore på 4,0. Den enkelte journalist har altså som regel en opfattelse af at, han/hun er mere etisk bevidst end kollegerne, og i begge tilfælde ligger placeringen i den øverste halvdel af spektrummet fra 1 til 6, som det ses af tabel 1 .

Det ser umiddelbart ud til, at der i ret stort omfang eksisterer en bevidsthed om journalistisk etik, men et andet og modsatrettet synspunkt på spørgsmålet om etisk bevidsthed kan udtrykkes i påstanden: „Det er i virkeligheden meningsløst at tale om journalistisk etik, fordi journalister er dybt uenige om, hvad der er etisk og uetisk“, som undersøgelsens deltagere blev præsenteret

\section{Tabel 1.}

Placering af egen grad af bevidsthed om journalistisk etik, samt placering af graden af bevidsthed hos journalister generelt. Skala fra 1 (er i meget ringe grad bevidst om journalistisk etik) til 6 (er i meget høj grad bevidst om journalistisk etik). Procent

\begin{tabular}{lrrrrrrr}
\hline & $\mathbf{1}$ & $\mathbf{2}$ & $\mathbf{3}$ & $\mathbf{4}$ & $\mathbf{5}$ & $\mathbf{6}$ & I alt \\
\hline Placering af journalister generelt & 1 & 4 & 21 & 49 & 23 & 2 & 100 \\
\hline Placering af egen grad af bevidsthed & 0 & 1 & 2 & 15 & 56 & 26 & 100 \\
\hline
\end{tabular}

( $N=754$ og 746) 
for. Denne opfattelse deles imidlertid ikke af mange - 3 og 20 procent er henholdsvis helt enig eller delvis enige i påstanden, mens 20 procent er delvis uenige, og 58 procent er helt uenige $(\mathrm{N}=684)$. Langt de fleste mener altså, at der findes en fælles enighed om, hvad som er etisk og uetisk i journalistik. Hvad denne enighed omfatter vil blive beskrevet senere, mens før dette skal først kilderne til bevidstheden om etik beskrives, og omfanget af problemer med den journalistiske etik skal indkredses.

Dannelsen af en journalistik etik hos den enkelte journalist kan have mange kilder. Etik udspringer - på samme måde som den konventionelle sociologi beskriver grundlaget for holdninger og værdier - ikke af naturen, men af det sociale samspil mellem mennesker især gennem kommunikation og samtale mellem individerne i sociale gruppemæssige sammenhænge (Gundelach, 2002: 15-17). En anden sociologisk formulering af de samme erkendelser er de klassiske rolleteorier (Aubert, 1964/67: 45-68; Stehouwer, 1968: 32-37), som også findes som moderne videreudviklinger i de sociologiske nyinstitutionelle teorier (March \& Olsen, 1984). Mange af aspekterne i journalistisk etik kunne formentlig lige så godt analyseres som værdier/holdninger, roller eller institutioner, men mere vigtigt er den fælles påpegning i disse teorier af social interaktion, som skaberne af værdier, roller, institutioner og altså også etik.

Set i lyset af de forskellige sociologiske teorier peger deltagerne i undersøgelsen i tabel 2 i overraskende stort omfang på egne overvejelser og erfaringer, som vigtige kilder til skabelsen af den enkeltes egen opfattelse af journalistisk etik. Dette kan selvfølgelig være udtryk for en overvurdering af egen rolle i skabelsen af den personlige etik. I næste lag kommer de nære omgivelser, i form af samtaler med kolleger, samt observationer af fejl på egen arbejdspladser. Også fejl i pressen generelt, samt egen uddannelsen ligger i mellemgruppen. Klart mindst betydning tillægges fagblade og tidsskrifter, ledelsen på egen arbejdsplads, bøger og anden litteratur, og helt isoleret i bunden ligger Pressenævnet. Det store flertal af deltagere i undersøgelsen mener, at Pressenævnet har ringe eller slet ingen betydning for den enkelte deltagers egen opfattelse af journalistisk etik, hvilket er meget overraskende i forhold til den betydning nævnet ofte tillægges i den 


\section{Tabel 2.}

Vurdering af hvor vigtige forskellige kilder har været for skabelsen af den enkelte respondents egen opfattelse af journalistisk etik. Procent og procentdifference (Diff.)

\begin{tabular}{lcc|cc}
\hline & $\begin{array}{c}\text { Slet } \\
\text { ikke eller } \\
\text { mindre } \\
\text { vigtigt }\end{array}$ & $\begin{array}{c}\text { Vigtigt } \\
\text { eller } \\
\text { meget } \\
\text { vigtigt }\end{array}$ & Diff. & (N) \\
\hline Mine egne overvejelser & 1 & 99 & 98 & (748) \\
Mine egne fejl & 10 & 90 & 80 & (736) \\
Samtaler med kolleger i hverdagen & 12 & 88 & 76 & (749) \\
"Skrækeksempler" fra danske medier & 16 & 84 & 68 & (746) \\
Min uddannelse & 23 & 77 & 54 & (746) \\
$\begin{array}{l}\text { Fejl hos de kolleger, } \\
\text { jeg har arbejdet sammen med }\end{array}$ & 28 & 72 & 44 & (714) \\
$\begin{array}{l}\text { Fagblade som Dansk Presse, } \\
\text { Journalisten osv. }\end{array}$ & 44 & 56 & 12 & (744) \\
$\begin{array}{l}\text { Ledelsen på de arbejdspladser } \\
\text { jeg har været på }\end{array}$ & 52 & 48 & $\div 4$ & (709) \\
Bøger og anden litteratur & 55 & 45 & $\div 10$ & (748) \\
Pressenævnet & 70 & 30 & $\div 40$ & (746) \\
\hline
\end{tabular}

offentlige debat af konkrete sager om journalistisk etik, og i den bredere generelle debat om journalistisk etik.

Det er derimod personlige overvejelser og erfaringer samt kollegiale fejltrin og diskussioner, som ser ud til at være vigtige for skabelsen af en journalistisk etik hos den enkelte, men hvor stor en rolle spiller etiske overvejelser og diskussioner i den praktiske arbejdsmæssige hverdag? Som det ses i tabel 3 gør næsten halvdelen sig daglige overvejelser over eget journalistisk arbejde, og andelen stiger til mere end 80 procent, når også ugentlige overvejelser om eget journalistisk arbejde medtages. Eksplicitte diskussioner med kolleger sker noget sjældnere, typisk ugentlig eller månedligt, mens diskussioner med ledelsen på arbejdspladsen er langt sjældnere og for næsten en fjerdeldels vedkommende aldrig forekommer. Diskussioner om journalistisk etik med fa- 


\section{Tabel 3.}

Hyppigheden af overvejelser og diskussioner om journalistisk etik. Procent

\begin{tabular}{|c|c|}
\hline \multicolumn{2}{|c|}{ Jeg gør mig etiske overvejelser om mit eget journalistiske arbejde . } \\
\hline - Dagligt & 48 \\
\hline - Ugentligt & 34 \\
\hline - Månedligt & 14 \\
\hline - Halvårligt & 3 \\
\hline - Årligt & 0 \\
\hline - Aldrig & 1 \\
\hline - I alt & 100 \\
\hline$-(N)$ & (717) \\
\hline \multicolumn{2}{|c|}{ Jeg diskuterer journalistisk etik med mine kolleger ... } \\
\hline - Dagligt & 8 \\
\hline - Ugentligt & 42 \\
\hline - Månedligt & 35 \\
\hline - Halvårligt & 8 \\
\hline - Årligt & 3 \\
\hline - Aldrig & 4 \\
\hline - I alt & 100 \\
\hline$-(N)$ & (712) \\
\hline \multicolumn{2}{|c|}{ Jeg diskuterer journalistisk etik med familie og venner ... } \\
\hline - Dagligt & 6 \\
\hline - Ugentligt & 34 \\
\hline - Månedligt & 35 \\
\hline - Halvårligt & 16 \\
\hline - Årligt & 4 \\
\hline - Aldrig & 5 \\
\hline - I alt & 100 \\
\hline$-(N)$ & (724) \\
\hline \multicolumn{2}{|c|}{ Jeg diskuterer journalistisk etik med ledelsen på min arbejdsplads } \\
\hline - Dagligt & 3 \\
\hline - Ugentligt & 13 \\
\hline - Månedligt & 29 \\
\hline - Halvårligt & 20 \\
\hline - Årligt & 11 \\
\hline - Aldrig & 24 \\
\hline - I alt & 100 \\
\hline$-(N)$ & (592) \\
\hline
\end{tabular}

milie og venner sker langt oftere og er næsten lige så udbredt som diskussioner med kolleger. 


\section{Er der problemer med den journalistiske etik?}

Som det fremgår af Pressenævnets praksis er der hvert år mere end 100 sager, hvor der klages over medier og journalister. Klagesagerne er dog formentlig kun en lille top af et langt større isbjerg af problemer med den journalistisk etik, hvilket også bekræftes i spørgeskemaundersøgelsen, hvor kun en fjerdedel af respondenterne kan følge med i danske medier i en uge uden at støde ind i eksempler på dårlig journalistisk etik, jfr. tabel 4. En fjerdel ople-

Tabel 4.

Hyppigheden af dårlig journalistisk etik. Procent

\begin{tabular}{lr}
\hline Jeg oplever eksempler på dårlig journalistisk etik i dansk presse ... & \\
\hline - Dagligt & 25 \\
- Ugentligt & 46 \\
- Månedligt & 24 \\
- Halvårligt & 4 \\
- Årligt & 1 \\
- Aldrig & 0 \\
\hline - I alt & 100 \\
- (N) & $(704)$ \\
\hline På de arbejdspladser, som jeg har været på, har jeg set eksempler & \\
på dårlig journalistisk etik ... & 6 \\
\hline - Dagligt & 20 \\
- Ugentligt & 31 \\
- Månedligt & 27 \\
- Halvårligt & 11 \\
- Årligt & 5 \\
- Aldrig & 100 \\
\hline - I alt & $(597)$ \\
- (N) & \\
\hline Jeg tager mig selv i at udøve dårlig journalistisk etik ... & 100 \\
\hline - Dagligt & $1550)$ \\
- Ugentligt & 3 \\
- Månedligt & 16 \\
- Halvårligt & 26 \\
- Årligt & 30 \\
- Aldrig & 24 \\
\hline - I alt & \\
- (N) & \\
\hline & \\
\hline
\end{tabular}


ver problemer dagligt, mens halvdelen ugentligt oplever eksempler på dårlig journalistik etik. Den enkelte journalist og den enkelte borger oplever jo journalistik i utallige medier hver dag, så et etisk fejltrin i et enkelt medie kan derfor opleves af mange forskellige personer. Eet enkelt eksempel på dårlig journalistisk etik kan, hvis det underkastes opmærksomhed i medierne - som eksempel Triple-A sagen, eller de tilbagevendende diskussioner om anvendelsen af skjult kamera - betyde, at mange journalister bliver opmærksomme på problematisk journalistisk etik. Derfor er det nødvendigt også at se på, om der på de enkelte arbejdspladser og hos den enkelte journalist opleves problemer. Som det ses i tabel 4 er oplevelsen af at finde eksempler på dårlig journalistisk etik typisk noget dagligt eller ugentligt i pressen som helhed. På egne arbejdspladser typisk noget månedligt eller halvårligt, mens det for eget arbejde falder til, at være noget som typisk sker halvårligt eller årligt.

Som næsten alle former for etik kan det ikke forventes, at etikken efterleves 100 procent hver dag af alle, så hvorledes kan tallene i tabel 1 vurderes - er det for mange eksempler? Er det forventeligt? Bør det blive bedre? Disse spørgsmål kan undersøgelsen ikke besvare, men spørgsmålene fortjener debat i offentligheden og blandt journalister, men resultaterne kan dog sættes i perspektiv på én måde, nemlig ved at sammenligne med situationen i udlandet. Deltagerne i undersøgelsen blev præsenteret for påstanden: „Den journalistiske etik har det bedre i Danmark end i de fleste andre lande“. Svarene viste, at 10 procent var helt enige, 60 procent var delvist enige, mens henholdsvis 19 og 5 procent er delvis uenige og helt uenig. Det skal dog bemærkes, at mere end 200 svarede „Ved ikke“ til spørgsmålet, formentlig fordi mange ikke har haft tilstrækkeligt god indsigt i medierne i andre lande til at ville fortage sammenligningen. Dette ændrer dog ikke på, at vurderingen af den journalistiske etik i Danmark må betegnes som positiv, dog uden at være overvældende, hverken når der sammenlignes med udlandet, eller når antallet af eksempler på dårlig etik betragtes - men hvordan vurderer journalister mere direkte deres egen og kollegernes udøvelse af journalistisk etik? 


\section{Tabel 5.}

Placering af i hvor høj grad man selv lever op til journalistisk etik, samt placering af i hvor høj grad danske journalister generelt lever op til journalistisk etik. Skala fra 1 (lever i meget ringe grad op til journalistisk etik) til 6 (lever i meget høj grad op til journalistisk etik). Procent

\begin{tabular}{lrrrrrrr}
\hline & $\mathbf{1}$ & $\mathbf{2}$ & $\mathbf{3}$ & $\mathbf{4}$ & $\mathbf{5}$ & $\mathbf{6}$ & I alt \\
\hline Placering af journalister generelt & 0 & 2 & 17 & 54 & 25 & 2 & 100 \\
\hline Placering af dig selv & 0 & 0 & 2 & 20 & 60 & 18 & 100 \\
\hline
\end{tabular}

( $N$ er henholdsvis 691 og 692)

På en seks-punkt skala, som går fra 1 (lever i meget ringe omfang op til journalistisk etik) til 6 (lever i meget højt omfang op til journalistisk etik), placerer journalisterne sig selv på en gennemsnitscore på 4,9, mens de placerer danske journalister generelt på en gennemsnitscore på 4,1. Den enkelte journalist har altså som regel en opfattelse af, at han/hun er bedre til at leve op til den journalistiske etik end kollegerne, og i begge tilfælde ligger placeringen i den øverste halvdel af spektrummet fra 1 til 6 , som det ses af tabel 5 .

Det positive billede - især af egne præstationer - leder dog ikke til en direkte afvisning af etiske problemer med den journalistiske etik. Stillet overfor påstanden: „Interessen for journalistisk etik er overdreven, da der i hele den danske medieverden i løbet af et år kun er få eksempler på problemer“, afviser de fleste påstanden: 27 og 59 procent var henholdsvis delvis uenige og helt uenig, mens kun 2 procent var helt enige og 12 procent delvist enige $(\mathrm{N}=683)$.

Selv om der på den ene side var en positiv vurdering af Danmark sammenlignet med udlandet, og selv om vurderingen af både kollegerne og især egen evne til at leve op til journalistik etik var positiv, så betyder de mange daglige og ugentlige eksempler på problemer med den journalistiske etik alligevel, at der ifølge deltagerne i undersøgelsen bør vises interesse for journalistiske etik. Men hvem har så ansvaret for at udvise denne interesse og sikre den journalistiske etik? 


\section{Ansvaret for journalistisk etik}

Som det ses i tabel 6 mener det store flertal, at det er den enkelte journalist, som selv har det primære ansvar for at sikre den journalistiske etik på en arbejdsplads, og hvis ikke det er den enkelte journalist, så er det fællesskabet og kollegerne, som gennem sparring, coaching og kritik skal sætte fokus på journalistisk etik. Kun cirka hver tiende mener, det er et ledelsesmæssigt ansvar. Dette blev antydet allerede i tabel 1, hvor egne overvejelser og erfaringer, samt kollegiale fejl og diskussioner, blev udpeget som vigtige til kilder for skabelsen af egen opfattelse af journalistik, mens ledelsen lå langt nede på listen over kilder. Det kunne dog forventes, at ledelsen fik en mere fremtrædende rolle, når det kom til ansvarsplaceringen, men ledelsen fik nærmere en mindre betydning.

Både tabel 1 og tabel 6 kan ses som udtryk for den på en gang meget individualistiske og samarbejdsorienterede kultur blandt journalister, samt måske et stænk af antiautoritet.

En anden fortolkning er, at netop fordi der er tale om etiske spørgsmål, så spiller individuelle overvejelser og personlig stillingtagen - samt et personligt ansvar - en stor rolle. En parallel kunne trækkes til lægeetik, som kunne formodes, at være præget af samme indstilling. Omvendt kunne forventningen til embedsmandsetik næppe i samme omgang være en stor vægtlægning på det personlige ansvar. Karakteristika ved professionen, men også

\section{Tabel 6.}

Ansvaret for sikring af journalistisk etik på en journalistisk arbejdsplads. Procent

\begin{tabular}{lr}
\hline Hvem har efter din mening det primære ansvar for sikring \\
af journalistik etik på en journalistisk arbejdsplads? ... \\
\hline - Det er primært den enkelte journalists eget ansvar \\
- Det er primært ledelsens ansvar & 61 \\
- Det er primært noget som skal sikres gennem & 13 \\
kollegial kritik, coaching og sparring & 21 \\
- Andre & 5 \\
\hline - I alt & 100 \\
- (N) & $(716)$ \\
\hline
\end{tabular}


forskellige kulturer og traditioner, kan være af betydning for graden af personlig ansvarsfølelse for sikringen af etikken.

En helt tredje fortolkning på den store personlige ansvarsfølelse, kan begrundes med tabel 7 , hvor det ses i svarene på det første spørgsmål, at ganske mange opfatter journalistisk etik,

\section{Tabel 7.}

Svarfordelingen på fire spørgsmål. Procent

\begin{tabular}{|c|c|}
\hline \multicolumn{2}{|c|}{$\begin{array}{l}\text { Journalistisk etik er i virkeligheden blot almindelige } \\
\text { håndværksmæssige krav ... }\end{array}$} \\
\hline - Helt enig & 45 \\
\hline - Delvis enig & 39 \\
\hline - Delvis uenig & 10 \\
\hline - Helt uenig & 6 \\
\hline - I alt & 100 \\
\hline$-(N)$ & (697) \\
\hline \multicolumn{2}{|c|}{$\begin{array}{l}\text { Journalistisk etik skal overholdes uanset om det betyder } \\
\text { tabet af en „forsidehistorie“ ... }\end{array}$} \\
\hline - Helt enig & 77 \\
\hline - Delvis enig & 17 \\
\hline - Delvis uenig & 4 \\
\hline - Helt uenig & 2 \\
\hline - I alt & 100 \\
\hline$-(N)$ & (706) \\
\hline \multicolumn{2}{|c|}{$\begin{array}{l}\text { Journalistisk etik skal overholdes uanset om det betyder, } \\
\text { at journalisten mister sit job ... }\end{array}$} \\
\hline - Helt enig & 49 \\
\hline - Delvis enig & 40 \\
\hline - Delvis uenig & 10 \\
\hline - Helt uenig & 1 \\
\hline - I alt & 100 \\
\hline$-(N)$ & (652) \\
\hline \multicolumn{2}{|c|}{$\begin{array}{l}\text { En journalist bør underrette ledelsen, hvis han/hun bliver opmærksom } \\
\text { på, at en kollega på arbejdspladsen groft har overtrådt journalistisk etik ... }\end{array}$} \\
\hline - Helt enig & 33 \\
\hline - Delvis enig & 45 \\
\hline - Delvis uenig & 14 \\
\hline - Helt uenig & 8 \\
\hline - I alt & 100 \\
\hline$-(N)$ & (651) \\
\hline
\end{tabular}


ikke som noget højtflyvende, dybsindigt eller nærmest religiøst, men derimod blot som nogle som nogle håndværksmæssige krav. Og hvis det er tilfældet, at det blot er håndværkmæssige krav, så er det meget forståeligt, at man vægtlægger det personlige ansvar og ikke skubber ansvaret opad til ledelsen.

De tre næste svar i tabel 7 tyder imidlertid på, at disse håndværksmæssige krav er af meget stor betydning. Overholdelsen af journalistisk etik er så vigtigt, at næsten alle mener, at en forsidehistorie må opgives, hvis den kræver overtrædelse af journalistisk etik. Halvdelen er ligeledes helt enig i, at et job i givet fald må sættes ind i forsvaret for journalistisk etik, og 40 procent er delvist enige, så selv et så drastisk skridt er der stor opbakning til. Når det kommer til underretning af ledelsen, hvis en kollega, groft har tilsidesat etikken, er cirka en fjerdedel helt eller delvis uenige, men stadig er tre fjerdedele helt eller delvist enige. På den ene side står altså tilslutning til opfattelsen af, at journalistisk etik „,blot“ er håndværksmæssige krav, på den anden side en lige så stor tilslutning til, at der i givet fald må bringes store ofre og kræves drastiske skridt i forsvaret for etikken.

Uanset hvilken tolkning, som er rigtig, står det tilbage, at journalistisk etik i meget høj grad er et personligt og kollegialt ansvar, og i meget ringe omfang opfattes som et ledelsesmæssigt ansvar.

\section{Holdningen til konkrete dele af journalistisk etik?}

Det er ikke muligt, inden for denne undersøgelses rammer, at lave en udtømmende afdækning af de mange forskellige elementer og dilemmaer, som indgår i journalistisk etik, og som ovenfor hos Randall var fokuseret på sandhedssøgen, objektivitet og upartiskhed. Med udgangspunkt i de „Vejledende regler om god presseskik“, blev nogle elementer udvalgt, som undersøgelsens deltagere blev præsenteret for.

Det ses i tabel 8, at der er forholdsvis stor tilslutning til næsten alle af disse ni delelementer, og med hensyn til hensyntagen til svage kilder, privatlivets fred og følsomme oplysninger er det nærmest total tilslutning. Også adskillelse af redaktionelle beslutninger fra økonomiske/annoncemæssige hensyn er det stor opbakning bag, mens der er forbehold fra hvert femte respon- 


\section{Tabel 8.}

Vurdering af hvor vigtige forskellige principper bør være som etisk regel i journalistik. Procent og procentdifference (Diff.)

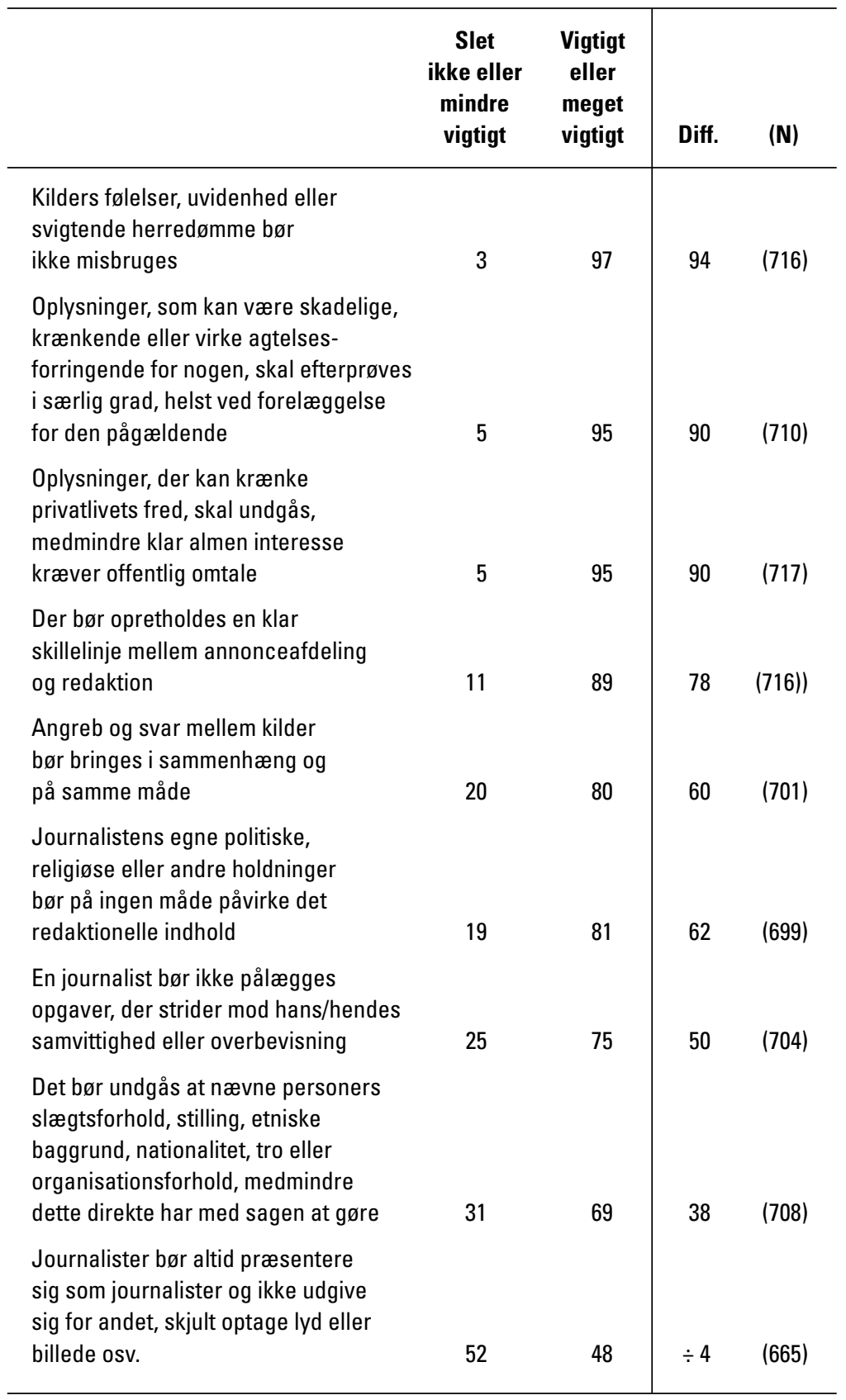


dent, når det kommer til spørgsmålene om dels den rolle journalisters egne holdninger kan spille og dels kontradiktionsprincippet - at en person eller organisation, som omtales har ret til at blive gjort bekendt med dette og svare på eventuelle anklager. Egentlig uenighed eller splittelse er der dog kun i spørgsmålet om at arbejde skjult uden at oplyse, at man er journalist, eller direkte med brug af skjulte lyd eller billedoptagelser.

\section{Konklusion}

Journalister må formodes at have et skarpere øje end gennemsnitsborgeren for journalistisk etik og ikke mindst brud på god journalistisk etik. Derfor er det af speciel interesse at undersøge, hvordan medlemmerne af Dansk Journalistforbund oplever og vurderer den journalistiske etik i Danmark, samt hvilke holdninger og værdier de har i forhold til journalistisk etik.

Undersøgelsen fra 2006 viser, at der er bred enighed om en række etiske principper, som beskyttelsen af privatlivets fred, svage kilder, forsigtighed i forhold til skadende, krænkende eller blot personlige oplysninger, at medier ikke må lade det redaktionelle styre af økonomiske/annoncemæssige hensyn, at journalister ikke må lade sig styre af egne holdninger, men omvendt ikke bør pålægges arbejde, som er i strid med sådanne holdninger og overbevisninger. Først når det kommer til spørgsmålet om at arbejde skjult opstår der en vis uenighed om de etiske målsætninger.

Undersøgelsen viser imidlertid også, at mange respondenter ser daglige eksempler på dårlig journalistisk etik, og de fleste oplever det ugentligt, men trods dette mener de fleste, at situationen i Danmark er bedre end i de fleste andre lande. Det er et gennemgående træk, at den enkelte journalist ser mere positivt på sin egen situation, end vurderingen af kollegerne på arbejdspladsen og især vurderingen af situationen blandt journalister og medierne generelt. Det gælder eksempelvis graden af bevidst om journalistisk etik, eksempler på at der udøves dårlig journalistisk etik, samt i hvilken grad man lever op til god journalistisk etik. Fænomenet, som nogle vil kalde selvovervurdering, er ikke ukendt fra undersøgelser af andre typer af adfærd. 
Dette ændrer ikke på, at der øjensynligt i høj grad eksisterer en personlig, men også fælles bevidsthed om journalistisk etik, og at denne har mange forskellige kilder, dog med personlige og kollegiale erkendelser og erfaringer, som de vigtigste. Egen uddannelse, samt læring fra skrækeksempler er også vigtigt, mens omvendt fagblade og litteratur samt ledelsen spiller en ringe rolle. Af særlig ringe betydning for skabelsen af egen opfattelse af journalistisk etik er Pressenævnet. Hvis dette organ ikke blot skal have karakter af et redskab til beskyttelsen af kilder, virksomheder og privatpersoner, er der brug for en storstilet pædagogisk indsats, som kan gøre opmærksom på det fejlagtige i den opfattelse - dette ry - eller også er der brug for at ændre Pressenævnets rolle fra den reaktive prøvelsesmulighed, til en mere proaktiv, debatskabende og uddannede enhed i stil med den rolle som Etisk Råd i mange tilfælde påtager sig.

For at vende tilbage til Sløks ord i starten af artiklen, så har analysen ikke givet den fulde forklaring på, hvad etik er for et dyr, men de første streger i omridset af dyret er blevet tegnet. At dyret er der, at det gives stor opmærksomhed, og at det på en gang er meget personligt og med mange fælleselementer, er tydeligt men også at problemerne med den journalistiske etik er mange.

\section{REFEREN CER}

Aubert, Vilhelm (1964/67). Sosiologi, 2. opplag, Oslo: Universitetsforlaget. Andersen, Michael Bruun (2006). „Fra presseetik til markedsmoral“, Journalistica, 1 . årgang, nr. 1.

Franklin, Bob, Martin Hamer, Mark Hanna, Marie Kinsey \& John E. Richardson (2005). Key Concepts in Journalism Studies, London, Thousand Oaks \& New Delhi: Sage Publications.

Glebe-Møller, Jens (1996). „Indledning“ i Jürgen Habermas Diskursetik, Frederiksberg: DET lille FORLAG, 1983/1996.

Gundelach, Peter (2002). „Værdier på dagsordenen“ i Peter Gundelach (red.). Danskernes vaerdier 1981-1999, København: Hans Reitzels For$\operatorname{lag} \mathrm{A} / \mathrm{S}$.

March, James G. \& Johan P. Olsen (1984) "The new institutionalism: Organizational Factors in Political Life", American Political Science Re- 
view, Vol. 78, pp. 734-749.

Randall, David (2000). The Universal Journalist. Second Edition, London \& Ann Arbor, MI: Pluto Press.

Skovbjerg, Annegrete \& Oluf Jørgensen (2006), „Presseetisk kontrol“, Journalistica, 1. årgang, nr. 1.

Sløk, Johannes (1993). Moralen, der blev vaek, uden sted: Centrum.

Stehouwer, Jan (1968). Sociologi, 2. udgave ved Ole Tonsgaard, København: Gyldendal. 